\title{
顔画像を用いた \\ 人物カラーイラスト作成システム
}

\author{
非会員 山 路憲 (慶応義塾大学) \\ 正員 萩 原 将 文 (慶応義﨏大学)
}

Color-Illustration Generation System from Facial Image

Ken Yamaji, Non-member, Masafumi Hagiwara, Member (Keio University)

We propose a new system for generation of a personal color-illustration from a facial image. The proposed system has the following features. It is possible to generate personal color-illustrations that take after the person in the input image. The system requires a small amount of user's operation using its interactive interface to obtain some facial information. Skin area of the illustration is painted the color just like the skin of input. The illustration is deformed to have facial expression, and to exaggerate the facial features. Some accessory parts are combined with the illustration. We confirmed the effectiveness of the proposed system by user survey.

キーワード：似顔絵, 肌色, 顔, HSV

Keywords: personal illustration, color of skin, face, HSV

\section{1. はじめに}

顔は，人のコミュニケーションにおいて重要な役割を 果たしている。これは，その人物の性別，年龄などの情 報，言葉だけでは表現しにくい感覚的なメッセージを持 つからである(1)。このため近年では，これら顔に関する 情報処理研究が盛んに行われている(2)ー(7)。また，顔の 持つ重要な情報を伝える媒体として人物イラストがある。 人物イラストは, 新聞, 書籍などの乗絵としての利用や 人物の風刺などの利用 ${ }^{(8)}$. ウェッブサイトや名刺 ${ }^{(9)}$ への 利用などもある。また，ヒューマンインターフェースな ど工学への利用も考えられている(10)。しかし，人物イラ ストを作成するには高度な作画技術が必要となる。この ためイラスト作画技術を持たない人が．目的の人物のイ ラストを得ることは困難である。そこで, コンピュー夕 にユーザが求める人物イラストを自動作成させる研究が 行なわれている。

人物イラストに関する研究として, 平均顔から特徴を 誇張する似顔絵生成手法 (11) -(13)や顔イラストに表情を付 加する研究 (14)(15)。さらにアミューズメント性や親しみ
易さなどを加味した顔イラストを作成する研究(16) (18)な どがある。しかし，これらが作成するイラストは白黒で描 画されており，顔の情報の一つである肌の色などを表現 することができない。また顔の特徴を得るために莫大な 入力作業が必要であったり，顔の特徵抽出を自動化した ため，顔から得る情報が不十分となり似顔としての精度 が劣るという問題があった。このような問題点とともに， 実際に書籍などの紙面を飾る実用的なイラストを考えた 場合，絵の綺麗さを実現することは非常に重要である。 そこで本論文では顔画像を用いた人物カラーイラスト 作成システムを提案する。提案システムでは，対話的な インターフェースを用い. 従来手法 ${ }^{(11)-(13)}$ と比べ非常に 少量で簡単な入力作業を経て人物イラストの作成が行な われる。イラスト描画に関しては，作画技術習得者の試 行錯誤により得た描画法が用いられる。これをもとに、入 力の人物に似たイラストの作成が行なわれる。また，肌 の色が本人らしさを出すために非常に重要であると考え， 肌の色の彩色が実現される。このとき，顔画像の肌色を もとにイラスト用の肌色を作成し，これを用い人物の肌 の色が反映された彩色が行なわれる。表情に関しては， 
作画技術習得者の試行錯誤により得られた基本的な表情 (喜び，驚き，恐机，怒り)の作成ルールが用いられ，デ フォルメされた表情が付与される。最後に，胴体や眼鏡 などの部品を加工し貼り付けることで様々なイラストが 作成される。

本論文では以下，2節でシステムの概要，3節で顔の特 徵の入力と抽出について，4節で顔の描画について，5節 で彩色，6節でデフォルメ，7節で装飾について述べる。 また，8節でシステム評価結果とその考察を述べ，9節で 結論を述べる。

\section{2. システムの概要}

図 1 にシステムの概要図を示す。提案システムは以下 の 5 つのステップから構成される。
(1) 顔特徵入力抽出
(2) 顔部品描画
(3) 彩色
(4) デフォルメ
(5) 装飾

顔特徴入力抽出部では，はじめに眉，目，口，鼻の特 徴点がユーザにより入力される。次に顔輪郭特徵点の自 動抽出とユーザの調整, 髪領域の自動抽出が行なわれる。 顔部品描画部では，まずスプライン曲線などを用いた目， 顔輪郭, 耳, 鼻筋の描画が行なわれる。次にアフィン変 換を用い特徵点に従い変型された眉, 口, 鼻の雛型画像 が描画される。彩色部では, 顔画像から得た肌色をもと にイラスト用肌色が作成され，この肌色を用いてイラス トの肌部分の彩色が行われる。次に顔の影部分が作成さ れ,この彩色も行なわれる。また, 髪領域の塗りつぶし により髪が描画される。デフォルメ部では, 平均顔との 差分により顔の特徵が誇張される。またユーザが選択し た表情が付加される。装飾部では，ユーザが眼鏡や胴体 といった部品を選択し, 顔イラストとの合成が行われる。

\section{3. 顔特徵入力抽出}

〈3・1〉顔特徵点の入力 図 2 に顔の特徵点を示す。 これら特徽点のなかで, 眉, 目, 口, 鼻部品に関しては ユーザが入力を行う (24 点)。これは正確な顔特徵抽出だ けでなく，ユーザによる意図的な変形，アレンジの可能 性が考慮されている。このように意図的な变形, アレン 汭できることは，ユーザの求めるイラスト作成におい て非常に重要であると考えられる。

〈3.2〉顔輪郭特徴点の自動抽出とユーザによる調節 顔輪郭特徽点 $\left(o_{0} \sim o_{N}\right)$ の作成の様子を図 3 に示す。 はじめに顎先が検出され，次に顔輪郭線の追跡が行なわ れる。最後に，この輪郭線が一定間隔でサンプリングさ れ，顔輪郭特徵点候補が作成される。その特徴点が顔輪

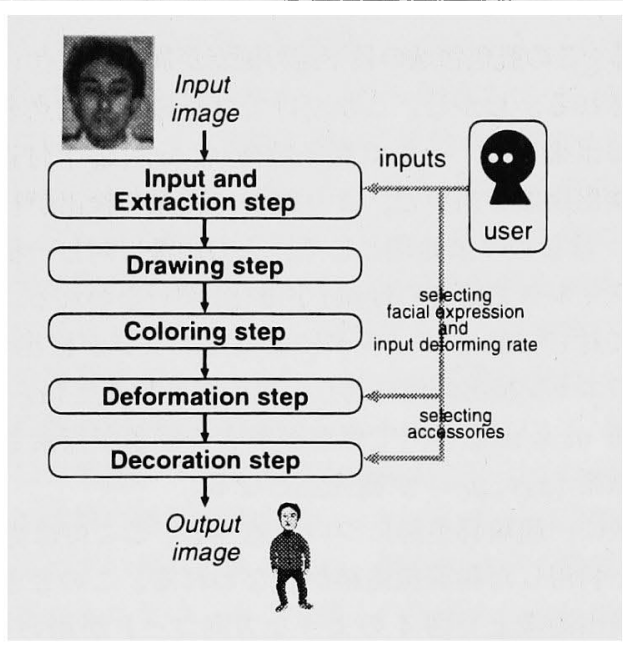

図 1 カラーイラスト作成システムの概要

Fig. 1. Outline of the proposed system.

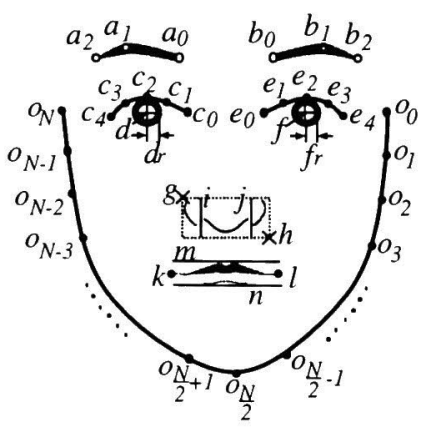

図 2 顔の特徵点

Fig. 2. Characteristic points of face.

郭と一致していなけ机ばユーザーが調節を行う。

はじめに顎先検出について述べる。顔画像において, 肌 色は YIQ 基底のIに特定の分布を持つことが知られてい る (19)。よって, RGB 基底の画像が $\mathrm{YIQ}$ 基底に変換さ れ処理が行なわれる。以下に RGB 基底から YIQ 基底へ の変換式を示す。

$$
\begin{aligned}
Y & =0.30 R+0.59 G+0.11 B \\
I & =0.60 R-0.28 G-0.32 B \\
Q & =0.21 R-0.52 G+0.31 B
\end{aligned}
$$

ここで，Yは輝度信号であり，Iは間隔信号， $Q$ は対角信 号である。次に, この式で得た YIQ 基底のIに対し閾值 処理が行なわれる。

$$
I_{\min }<I(x, y)<I_{\min }
$$

ここで, $I(x, y)$ は入力画像の画素 $(x, y)$ の $I$ 成分, $I_{\max }$, $I_{\text {max }}$ は閾値である。また, 上式を満たす画素が肌色領域と 
なる。この肌色領域の最下端の画素が顎先候補点 $\left(x_{C}, y_{C}\right)$ とされる。しかし，これだけでは正確な顎先点を得るこ とは出来ない。そこで顎先候補点 $\left(x_{C}, y_{C}\right)$ 付近のエッ ジ検出画像を用いた，より細かい顎先の検出が行なわれ る。はじめに前処理として, 入力画像に対し一様重み線 形フイル夕で雑音の軽減 (平滑化)が行なわれる。この画 像に対し Sobel フィルタによってエッジが検出される。 このエッジ検出画像に対し, 先の顎先候補点 $\left(x_{C}, y_{C}\right)$ の 近傍 $m \times n$ 空枠内で輝度が最大の画素が探索され, こ の画素 $\left(x_{C^{\prime}}, y_{C^{\prime}}\right)$ が顎先点となる。

次に, 顔輪郭追跡について述べる。ここでは方向コー ドを利用した輪郭線追跡が行なわれる。このとき，エッ ジ検出画像上で図 4 のような方コードが用いられる。 まず左側の顔輪郭線の場合について述べる。

（1）上述した Sobel フィルタによるエッジ検出画像 上の顎先の画素 $\left(x_{C^{\prime}}, y_{C^{\prime}}\right)$ に注目する。

(2) 図 4 に示寸の近傍画素 2 番加 3 番，4番の順 で輝度が最大の画素を探す。

（3）最大輝度の近傍画素を顔輪郭線上の点とし,こ れを注目画素とする。また，最大輝度の画素が2 つ以上の場合，番号の若い近傍画素を最大七する。

（4）新たな注目画素に対し (2)，(3) を適用し, 次の 注目点を探す。

これらは, 注目画素が下式の条件を満たすまで行なわれる。

$$
y_{A} \geq \frac{\left(y_{d}+y_{f}\right)}{2}
$$

$\left(x_{A}, y_{A}\right)$ は注目画素の座標, $\left(x_{d}, y_{d}\right),\left(x_{f}, y_{f}\right)$ は左右 睲の中心点の座標である。以上条件式を満たし顔輪郭線 の左側の追跡が完了となる。また右側の輪郭線を得るに は, 同様の手順が図 4 の近傍画素 6 番から 5 番, 4 番の 順で行なわれる。

次に, サンプリングによる顔輪郭特徴点の作成につい て述べる。四 3 (c) にその様子を示す。サンプリングは

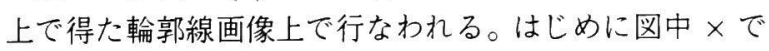
示される左右睲の中心点の重心を原点とおき，次に画像 右側のこめかみの方向を 0 度とおく。ここから $\theta$ 度毎に サンプリングが行なわれる。このサンプリングでは，原 点から $n \theta$ 度方向の線と輪郭線の交点が求められ, この 点が顔輪郭特徵点候補とされる。また $n \theta$ が 180 度まで 達すると終了となる。このようにして顔輪郭特徽点候補 が作成される。

最後に, 図 3 (d) のように, 各点が正しい輪郭線に合 うようにユーザが調節を行なう。

〈3.3〉髪領域の抽出 入力画像の髪は黒や焦茶色の 暗い色と想定される。このとき, 髪領域は顔画像におい て低輝度の領域であると考えられる。そこで入力画像の

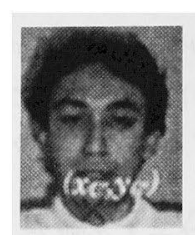

(a) 顎 先

検出

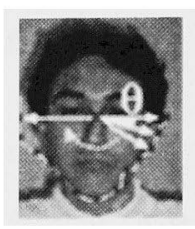

(c) サンプ

リンダ

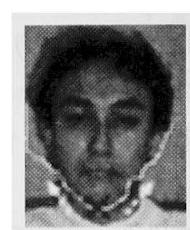

(b) 顔輪

郭追跡

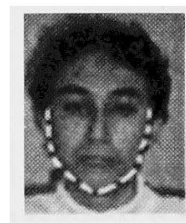

(d) 調節
図 3 顔輪郭自動抽出とユーザによる調節過程

Fig. 3. Semi-automatic extraction of jawline and user's adjustment.

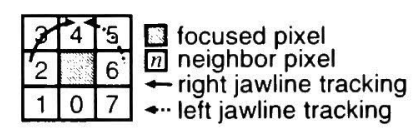

図4方向コードを用いた輪郭追跡

Fig. 4. Freeman's chain code for tracking outline.

YIQ 基底の $Y$ 成分に対し以下の閾值処理が行なわれる。

$$
Y(x, y)<Y_{\theta}
$$

ただし, $Y(x, y)$ は画素 $(x, y)$ の $Y$ 成分, $Y_{\theta}$ は閾值であ る。また,この式を満たす低輝度の画素が髪領域となる。

\section{4. 顔部品描画}

本システムの描画手法では, 似ていることだけでなく, 絵の綺麗さなども考慮し筆者らのコンピュータによるイ ラスト作画経験に基づき構成されている。

〈4・1〉 スプライン曲線などで描画する部品顔部品 (顔輪郭, 目, 耳, 鼻筋) は, スプライン曲線や円を用い 描画される。

顔輪郭では, 顔輪郭特徵点 $\left(o_{0} \sim o_{N}\right)$ が自由端末条 件の 3 次スプライン曲線で結ばれ描画される。これ以降, スプラインは自由端末条件の 3 次スプラインを指すこと とする。

目の描画では，両まぶたの輪郭の点それぞれ 5 点 $\left(c_{0} \sim\right.$ $\left.c_{4}, e_{0} \sim e_{4}\right)$ がスプライン曲線で結ばれ描画される。瞳 は, 2 つの中心点 $d$ と $f$ に半径 $d_{r}$ と $f_{r}$ の円が描か 


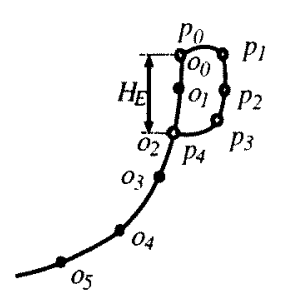

(a) 耳 (右睢)

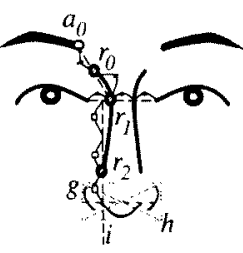

(b) 鼠筋

\section{図 5 耳、鼻筋の描画}

Fig. 5. Drawing spline curve for ear or nosebridge.

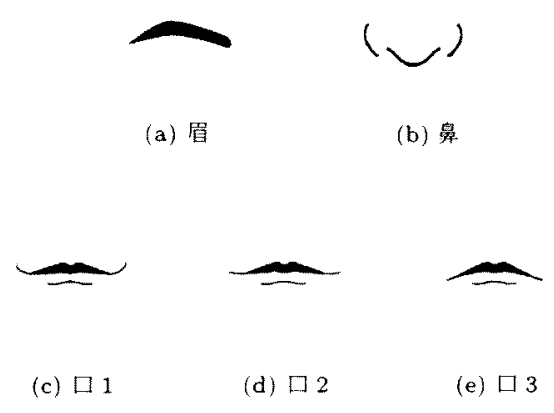

図 6 雛型画像

Fig. 6. Template parts

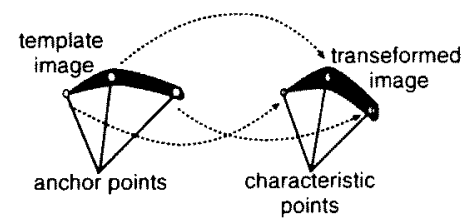

図 7 眉毛雊型画像のアフィン変換

Fig. 7. Affine transeform for eyebrow.

れる。

またまぶたには一般的に一重，二重が存在する。そこ でユーザはどちらの描画を行うかを選択する。二重が 選択された場合は両まぶたの輪郭の点 $\left(c_{0} \sim c_{4}, e_{0} \sim e_{4}\right)$ を平行移動した点を作成し，同じくスプラインで結び，上 述したまぶたの曲線と共に描かれる。

また，耳や鼻筋などは，図 5 に示寸ように，既にある 特徵点を用い算出する。耳の場合は，顔輪郭特徵点を元 に耳の大きさを推定し、これを元に座標を作成する。鼻 能の場合は，目や眉，鼻の距離の比率を元に算出する。 〈4·2〉雊型画像を用いる部品図6(a)〜 (e) に眉, 鼻, 口部品の雊型画像を示す。これら画像は〈3・1〉節で得 た特徴に従いアフィン変換を用いて変型され描画される。 まず眉の描画について述べる。図 7 は左眉の変換の様 子を示したものである。このように，入力された顔の特徴 点上雛形画像の対応点よりアフィン変換行列を求め, 雛 型画像にアフィン変換を施し変形する。この変換した画 像を固の特徴点 $\left(a_{0} \sim a_{2}, b_{0} \sim b_{2}\right)$ の位置八貼付けるこ とで眉の描画が行なわれる。

次に口の描画について述べる。図 6 (c)～(e) に示すよ うに, 3 種類の雊型画像が用いられている。口は個人の 特徴が出やすい部品であるため, 触型画像が 1 種類では 特徽を捉えきれない。そこで個人の特徴をより反映する ためこれら 3 種類が用いられる。雊形画像の選択は下式 にしたがって行な秃る。

$$
\begin{cases}\text { Type } 1, & y_{k}>y_{m} \text { or } y_{l}>y_{m} \\ \text { Type } 2, & y_{n} \leq y_{k} \leq y_{m} \text { and } y_{n} \leq y_{l} \leq y_{m} \\ \text { Type } 3, & y_{k}<y_{n} \text { or } y_{l}<y_{n}\end{cases}
$$

ここで, $y_{k}$ と $y_{l}$ は口の左右両端の点 $k$ と $l$ の 座標, $y_{m}$ と $y_{n}$ はそれぞれ上唇上端，下唇下端の $y$ 座標であ る。ここで得られた雛型画像は〈3・1〉節で得た口の幅, 高さに拡大縮小される。この画像を点 $k, l, m, n$ の位置 八貼付けることで描画が行なわれる。

最後に鼻の描画について述べる。図6 (b)に鼻の雛型画 像を示す。鼻は個人の特徵を細かく反映させるため, 左 右小鼻, 鼻頭の 3 つ部品にわけられている。この勧型 画像を, 小鼻幅, 鼻頭幅, 高さに拡大蓿小儿, 点 $g, h, i, j$ の位置へ貼付けることで描画が行なわれる。

\section{5. 彩色}

本システムの顔イラストの彩色には以下の 3 つがある。

（1）指定色で彩色 (スプライン曲線，矮等)

（2）彩色済の画像を利用 (雛型画像)

（3）肌の色にしたがった彩色

本節では，(3)の顔画像の肌の色にしたがった彩色と，(1) の特に鬆の彩色について述べる。

〈5・1〉肌の色の抽出と作成肌の色にしたがって彩 色を行なう際，まず肌の色が抽出され，それをもとにイ ラスト用の肌色が作成される。

肌の色の抽出では, 顔の肌の色の特定領域の平均値が 計算される。この領域には, 鼻頭, 左右煩の3つが用い られる。これは，この領域が比較的陰になりにくいから である。

このとき，抽出された平均色では，カメラや照明の具 合によって黒ずんだ色になってしまうことがある。これで はユーザが満足する出力を得られないため，次にイラス

巣学論C, 122 巻 5 号, 平成 14 年 
ト用肌色が作成される。この肌色を作成するため，上で 抽出した肌色は HSV 基底に変換され， $h_{\text {ave }}, s_{\text {ave }}, v_{\text {ave }}$ が求められる。ここで HSVを用いるのは，後で述べる 変換において, 特に彩度 $S$ の変化により肌の色白から色 黑への变化が比較的容易に表現できるからである。また， $\mathrm{RGB}$ 基底から HSV 基底へ変換を行う式を以下に示す。

$$
\begin{aligned}
& H= \begin{cases}\frac{\pi}{3} \frac{B-R}{\max -\min } & \text { if } G=\max \\
\frac{\pi}{3}\left\{2+\frac{R-G}{\max -\min }\right\} & \text { if } B=\max \\
\frac{\pi}{3}\left\{4+\frac{B-R}{\max -\min }\right\} & \text { if } R=\max \end{cases} \\
& V=\max \ldots \ldots \ldots \ldots \ldots \ldots \ldots \ldots \\
& S=\frac{\max -\min }{\max }
\end{aligned}
$$

また，Hは色相，Sは彩度，Vは強度， $\max と \min$ はそ れぞれ RGB 要素の最大と最小の值である。ここで, 変 換された $h_{\text {ave }}, s_{\text {ave }}, v_{\text {ave }}$ が下式に代入され，イラスト用 肌色が求めら机る。

$$
\begin{aligned}
& h_{I}=H_{I}+\sigma_{H}\left(h_{\text {ave }}-H_{\text {ave }}\right) \\
& s_{I}=S_{I}+\sigma_{S}\left(s_{\text {ave }}-S_{\text {ave }}\right) \\
& v_{I}=V_{I}+\sigma_{V}\left(v_{\text {ave }}-V_{\text {ave }}\right)
\end{aligned}
$$

ここで, $h_{I}, s_{I}, v_{I}$ は求める色, $h_{a v e}, s_{a v e}, v_{a v e}$ は上で 求めた平均色の $\mathrm{HSV}$ 基底である。また， $H_{I}, S_{I}, V_{I}$, $H_{a v e}, S_{a v e}, V_{a v e}, \sigma_{H}, \sigma_{S}, \sigma_{V}$ は定数である。上式は, 肌 の色の平均的な値 $H_{a v e}, S_{a v e}, V_{a v e}$ 上入力画像の肌色の值 $h_{\text {ave }}, s_{\text {ave }}, v_{\text {ave }}$ の差を取り，それをある割合 $\sigma_{H}, \sigma_{S}, \sigma_{V}$ で定数 $H_{I}, S_{I}, V_{I}$ に加算することで肌の色を反映させ るものである。

〈5・2〉 悓の彩色 〈5・1〉節でイラストに彩色するた めの肌色 $h_{I}, s_{I}, v_{I}$ が作成され，この色で顔イラストの 肌部分が塗りつぶされる。また彩色時に簡単な影をつけ る。これは, 顔輪郭線を平行移動した線を境界とし, 求 めた肌色とその色の強度を抑えた暗めの色で塗り分ける ものである。

$\langle\mathbf{5} \cdot \mathbf{3}\rangle$ 髮の彩色 $\langle 3 \cdot 3\rangle$ 節で低輝度領域が髮領域 として抽出された。しかし、このままの髮領域では細か い線が描画されてしまう。この場合, 他の描画した部品 とのバランスを崩し, ユーザの満足する出力が得られな いことがある。そこで，丸まった領域を作成するため，鬆 画像は平滑化さ机細かな成分が除去される。次に，下式 に従って 2 值化される。

$$
Y(x, y)<Y_{\lambda}
$$

ここで, $Y(x, y)$ は平滑化後の画像の輝度值， $Y_{\lambda}$ は間値 である。この式を満たす画素を黒で塗りつぶすことで髮 の彩色が行なわれる。

\section{6. デフォルメ}

〈6.1〉 誇張本システムでは, 平均顔仮説 (12) に基ついた特徵の誇張(11)(12)(14)を行なう。ここでは，ま ず多数の人物の顔特徽の算術平均值が求められ，これが 平均顔とされる。そして新たに入力された顔特徽との差 を求め,この差分を強調することで入力顔の特徵が誇張 される。

平均顔を作成するために，顔特徵量の正規化が行われ る。正規化の基準として顔輪郭特徵点の両端点 (左右こ めかみの点)を用い．全てのサンプルにおいてこの2点 の距離，傾きが全て等しくなるように正規化される。

これら正規化された特徴量を用いて，下式に従い平均 顔を作成する。

$$
x_{i}^{(\text {ave })}=\frac{1}{M} \sum_{j=1}^{M} x_{i}^{(j)}
$$

ここで，第 $j$ 番目の人物の $i$ 番目の顔特徴を $x_{i}^{(j)}, M$ 人の平均を $x_{i}^{(\text {ave })}$ とする。

誇張は中割法(11)(12)(14)を修正した下式に基づいて行 なわれる。

$$
P^{(\text {out })}=P^{(\text {in })}+a_{p}\left(P^{(\text {in })}-P^{(\text {ave })}\right)
$$

ここで, $P^{(\text {in) }}$ は入力されたある顔部品の特徵量の集合, $P^{\text {(out) }}$ は誇張後, $\alpha_{P}$ は $P$ 顔部品に対する誇張率であ る。また誇張率 $\alpha_{P}$ は，各顔部品毎に誇張率を調節する ために用いられている。このように $a_{p}$ を各顔部品で設定 することで, 差 $\left|P^{(\text {in })}-P^{(\text {ave })}\right|$ が小さな顔部品を十分 に誇張させるとき，差が大きな部品が極端に変形され ラストが崩れてしまうことを防いでいる。

$\langle 6 \cdot 2\rangle$ 表情付加 本システムでは，基本的な表情 (喜び，驚き，恐れ，怒り)の付加が行なわれる。ここで いう表情は親しみやすさや分かりやすさを得るため，奏 際の表情ではなくデフォルメされたものである。また，書 籍等(8)をみてもこれらのような表情が多く使われて扔り， 実用面から見ても有効であると考えられる。

表情を付加する際，顔特徴または描画に対し次のよう なルールが適用される。これらルールは，筆者が表情の あるイラストを描く場合の主だったものを単純化したも のである。

喜び

$$
\begin{aligned}
& \text { ○口の雛型画像を喜びに変更 } \\
& \text { ○左右眉を頍上万向へ平行移動 } \\
& \text { ○左右上まぶたを頭上方向へ平行移動 } \\
& \text { ○口の雊型画像を驚きに恋更 }
\end{aligned}
$$$$
\text { 驚き }
$$ 


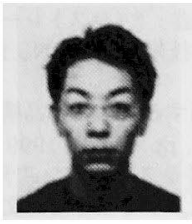

(a) 入力

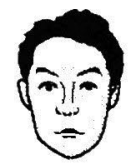

(b) 出力

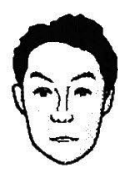

(c) 誇張

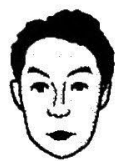

(d) 喜び

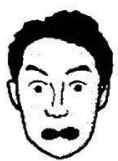

(e) 警き

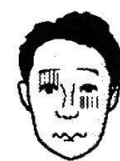

(f) 恐れ

(g) 怒り
図 8 顔イラスト出力

Fig. 8. Outputs(facial images)

恐れ

○左右眉を眉尻の点を中心に頭上方向へ回転 ○口の雊型画像を恐㞦に変更

怒り

○左右眉を眉間よりの点を中心に頭上方向へ回転 ○口の雊型画像を怒りに恋更

\section{7. 装飾}

よりその人らしさを表現するため，眼鏡や胴体 (服装) といった部品の合成を行う。また, 複数の部品の中から ユーザが選択することで，好みのイラストに仕上げるこ とが可能である。このとき，眼鏡，胴体部品は，できた 顔イラストのサイズにより拡大, 縮小され合成される。

\section{8. システム評価結果と考察}

提案システムでは，入力としてデジタルカメラで撮影 した画像を用いた。入力画像は以下の条件を満たすもの を使用した。

-頭部のみの画像

・明るい場所で撮影

・背景なし

・黒, 焦茶色などの暗い色の頭髪

・ 24 ビットフルカラー

- 縦 200 ピクセル. 横 100 ピクセル程度のサイズ 図 8 に提案システムにより作成された顔イラスト例を 示す。図 9 に胴体，眼鏡などを付けた例を示す。

また，これらイラストを作成したユーザ (11 名)に以
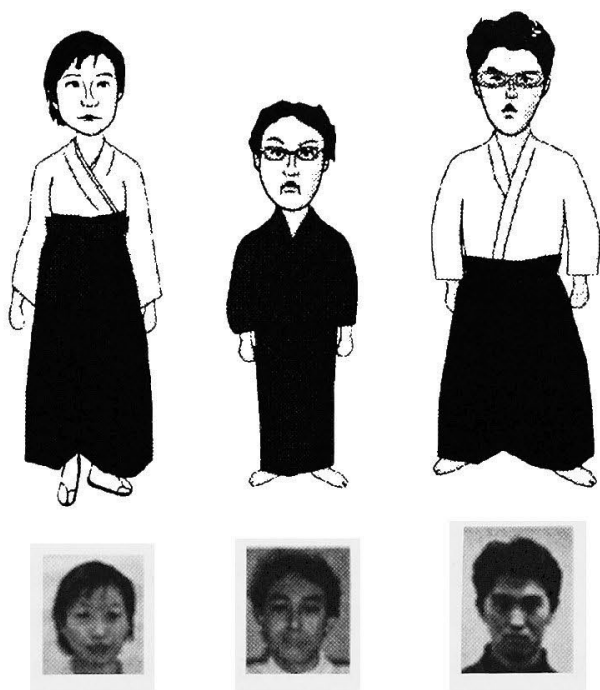

図 9 出力例 (胴体付き)

Fig. 9. Outputs(decolated)

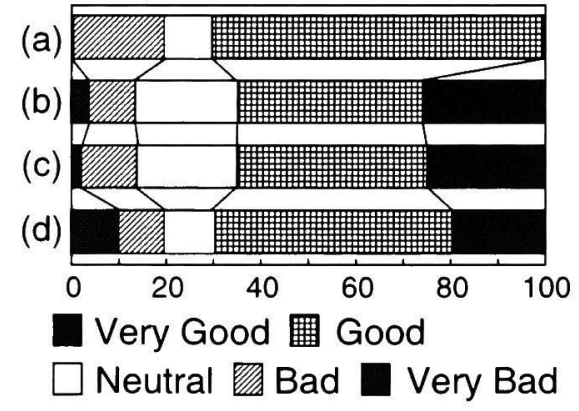

図 10 アンケート結果

Fig. 10. Results of user survey
下のようなアンケート調査を行った。
(a) 似ているか (本人評価)。
(b) 似ているか (第三者評価)。
(c) 適当な肌の色が彩色されているか。
(d) 入力作業は簡単であったか。

図 10 に結果を示す。この図を見ると，(a)〜 (c) におい ては，どの項目に関しても $60 \%$ 以上の人が良い」以上 の評価, $80 \%$ 以上の人が「普通」以上の評価をしている。 一般的に人が書いたイラストにおいての評価も十人十色 であることを考虑すれば，十分に有効であると考えられ る。また，(d)においてもシステムの使いやすさを十分 に示していると言える。

電学論C, 122 巻 5 号, 平成 14 年 


\section{9. 結論}

本論文では，顔画像を用いた人物カラーイラスト作成 システムを提案した。またシステム評価実験を行ない以 下のことを確認した。

・カラー化, デフォルメされた表情の付加，胴体や眼 鏡などの装飾によりユーザが望み，実用性のあるイ ラストを作成することができる。

・少量で簡単な入力作業のみでイラストの作成がで きる。

・少量の入力作業からでも詳細に顔の特徵を描画で き，似顔としてユーザが満足する精度を得ることが できる。

また今後の課題として, 完全な顔特徵の自動抽出, 敂 や細かい陰影などの描画や彩色，体格などを考慮した胴 体の作成，より多様な表情の付加などがあげられる。

本研究の一部は、日本学術振興会未来開拓事業 (JSPSRFTF 97 I 00103) の助成を受けて行われた。

(平成 13 年 5 月 30 日受付，同 13 年 12 月 17 日再受付)

\section{文 献}

（1）赤松茂：“コンピュータで探る顔の感性的イメージ,”日本ファ ジィ学会誌 Vol.10, No.2, pp.225-235, 1998.

（2）栗田多喜夫, 長谷川修：“顔画像觇の個人識別,”映像メディア 学会誌 Vol.51, No.8, pp.1132-1135, 1997.

(3) Y. H. Kwon and N. V. Lobo: "Age Classification from Facial Image," Computer Vision and Image Understanding Vol.74, No.1, pp.1-21, 1999.

（4）志賀泰博, 海老根秀之, 中村納：“表情認識のための顔器官お よび表面からの特徵量の抽出," 情報処理学会研究報告 Vol.99, No.69(HI-84), pp.97-104, 1999.

（5）間賴健二。“表情の自動認識,”映像情報メディア学会誌Vol.51, No.8, pp.1134-1139, 1997

（6）尾田政臣，山口真美, 小川徳子, 赤松茂 “顔写真をもとにした 表情認知と合成,”信学技報 Vol.99, No.451(HIP99 33-46), pp.13-18, 1999.

（7）黑田勉, 渡辺富夫 “情動变動における顔色の動的変化の解析,” ヒューマンインターフェースシンポジウム'99 pp.575-578, 1999.

（8）山藤章二：“似颜絵," 岩波新書, 2000.

（9）i-名刺 似顔絵名刺, http://www.i-meisi.com/

（10）西松豊典, 安井聡, 鳥羽栄治, 村上和人, 興水大和: “片 ンインターフェースへの似顔输の応用,”信学論 A Vol.J80-A, No.8, pp.1260-1265, 1997.

(11) K. Murakami, H. Koshimizu, A. Nakayama, and T. Fukumura : "Facial caricaturing based on visual illusion," IEICE TRANS. INF. \& SYST. Vol.E76-D, No.4 pp.470-478 1993.

（12）舆水大和, 吉田勝彦： “コンピュータ PICASSO と作家吉田勝彦 の似顔絵生成プログラム," バターン計测シンポジウム資料 Vol.3, pp.31-36, 1998.

（13）徐光哲，金子正秀，榑松晶 “顔部品の形状特徴と配置特徽の 强調による似顔絵の生成,”信学技報 Vol.99, No.452(HIP99 47-55), pp.19-24, 1999.

（14）村上和人，舆水大和“似顔絵生成と表情生成の統合について” テレビジョン学会誌 Vol.50, No.10, pp.1515-1521, 1996.

（15）岩下志乃, 武田夕紀, 鬼沢武久。“表情豊かな似顔絵描写,”電気学 会システム制御 研究会資料, Vol.SC-99, No.24-32, pp.17-22,
1999.

（16）川出雅人, 細井聖, 田畑尚宏, 秋間正道: “イラストレー夕の画風を 実現する似顔絵自動作成技術,”信学技報 Vol.97, No.117(HIP97 1-10), pp.33-40, 1997.

（17）藤井徹, 青木晃郎：“似顔絵を描画するための部品構成,” OMRON TECHINICS Vol.39, No.1, pp.86-90, 1999.

（18）片岡真紀：“顔の印象を反映するイラスト作成システム,”㕌應 義熟大学大学院 理工学研究科電気工学専攻修士論文 1999 .

（19）阿部友一，萩原将文：“単眼視動画像加ら人物頭部動作の解析 と認識," 信学論 D-II Vol.J82-D-II, pp.1-9 1999.

（20）安居院猛, 長尾智晴. “画像処理と認識,”昭晃堂, 1992.
山路

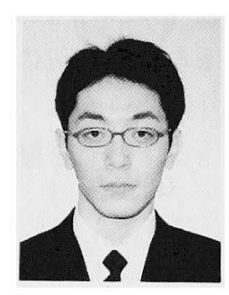

（非会員）平成 13 慶大·理工·情報卒. 現在, 同大大学院修士課程在学中。
萩 原 将 文 (正員) 昭 57 慶大·理工·電気卒。昭 62 同大大

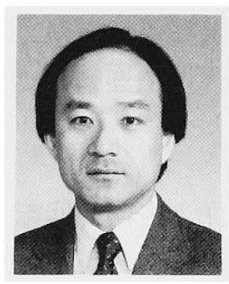
奨励賞, 1996 年ファジイ学会著述賞受賞。 学院博士課程了。工博。同年同大助手。現在, 同 大教授。1991 年より 2 年間アメリカStanford大 学訪問研究員。ニューラルネットワーク,ファジー システム, GA の研究に従事。工学博士。1986年 丹羽記念賞, 1987 年電子情報通信学会学術奖励 賞, 1990 年 IEEE 論文賞, 1994 年安藤記念学術 